\title{
POTENTIAL HEALTH RISKS FROM POSTULATED ACCIDENTS INVOLVING THE Pu-238 RTG \\ ON THE ULYSSES SOLAR EXPLORATION MISSION
}

\author{
Marvin Goldman \\ VM: Radiological Sciences \\ University of California \\ Davis, CA $95616-8742$ \\ (916) $752-1341$ \\ Robert C. Nelson \\ EG\&G Idaho, Inc. \\ P.O. Box 1625 \\ Idaho Falls, ID 83415 \\ (208) $526-6315$ \\ Lance Bollinger \\ DET 1 AFISC/SNR \\ Kirtland AFB, NM 87117-5000
}

(505) $844-6689$

\author{
Mark D. Hoover \\ Inhalation Toxicology Research Institute \\ P.O. Box 5890 \\ Albuquerque, NM 87185-5890
}

(505) $844-2306$

\author{
William Templeton \\ Battelle/Pacific Northwest Labs \\ 8th Street Warehouse/K1-30 \\ Richland, WA 99352 \\ (509) $375-3630$ \\ Lynn Anspaugh \\ Lawrence Livermore Laboratories \\ 7000 East Avenue \\ Livermore, CA 94550
}

(415) $422-3840$ 
The probability of a mission failure for any reason whatsoever is about one in a hundred; however, the probability that the failure includes an accident severe enough to cause a release of a fraction of the onboard plutonium was estimated to be about one in 10,000 for one case and less than one in 100,000 for the other accident scenarios. Although the probabilities of such accidents occurring are remote, the purpose of this report is to describe what might have happened to the plutonium if the accidents had occurred in either a local or worldwide release scenario, and what the consequences would be to human beings and the life around them.

What we have attempted in this report is called "risk assessment". Consciously or subconsciously, everyone does risk assessment. For example, when each of us decides whether or how to cross a street, although the decision often seems spontaneous, we are undergoing risk assessment. We are weighing the variables and calculating the probabilities. In that circumstance, most adults have had sufficient experience to make intelligent choices. We have seen cars and trucks on the road. We have seen them mixed with motorcycles, bicyclists, and pedestrians. We have witnessed the traffic going fast and slow, crowded and sparse, even erratic, and predicted the chances of our success negotiating through it. We have crossed the street properly at the crosswalks, and probably jaywalked, too. Regardless of the extent of our experience in crossing streets, most adults have lots of information and the freedom of choice in making decisions of survival. In the matter of satellites powered by ${ }^{238} \mathrm{Pu}$, most adults have had little or no information and thus certainly no freedom of choice. We have tried to remedy that situation with this article.

\section{THE NEED FOR RADIOISOTOPE THERMOELECTRIC GENERATORS}

Over the last 30 years, NASA has used ${ }^{238} \mathrm{Pu}$ to power 23 space missions, including Pioneer 10 and 11 (still operating after 19 years), the Viking mission to Mars, and the Voyager I and II grand tours of our planetary system. Last year's launch of Galileo also used ${ }^{238} \mathrm{Pu}$ to power its instruments. The ${ }^{238} \mathrm{Pu}$ has been used in devices called radioisotope thermoelectric generators (RTGs), which use the heat of radioactive decay to cause an electric current to flow through specially designed bi-metallic interfaces. RTGs have been demonstrated to be highly reliable sources of electrical power.

The space agency uses RTGs for deep space missions because, at present, there are no practical alternatives. With an energy requirement of up to several hundred watts of electrical power for several years, the space probes travel too far from the sun to use solar energy to provide that power. For example, solar cells to power Ulysses, which enters its polar orbit near Jupiter where the sun's intensity is only $4 \%$ of that on Earth, would have to weigh 1250 pounds and spread over 500 square feet. The weight would be too excessive to launch (the RTG only weighs 124 pounds). Fuel cells or batteries, another obvious choice, cannot be used on such a long mission because they need a power source, such as solar panels, for recharging, and their weight would be prohibitively heavy.

Concern for the safety of RTGs has always been a part of the U.S. space program, and design of the RTGs has evolved from a health protection philosophy of "dilution" and "dispersion" to one of "containment". The earliest plutonium power sources, preceding the current RTGs, were designed to burn up at high altitude. One power source fueling a Navy navigational satellite did burn up on accidental orbital reentry to the earth's atmosphere, leaving 17,000 curies of ${ }^{238} \mathrm{Pu}$ (about 3 pounds) in a dilute band around the Earth. Since then, the RTGs have been designed to contain the plutonium in case of an accident. The ${ }^{238} \mathrm{Pu}$ is encased in an iridium metal shell surrounded by two graphite shells, and these are inside another modular container to provide further protection. Three subsequent accidents served to prove the efficacy of the multilayered container design philosophy: two plutonium heat sources were recovered after they landed intact in the Pacific Ocean in 1968 after a weather satellite failed to reach orbit, and their fuel was used in a later mission. Another heat source fell into the South Pacific Ocean after separating from an Apollo 13 command module; the subsequent search turned up no evidence that ${ }^{238} \mathrm{Pu}$ was released. Only if an RTG hits something as hard as granite on its plunge back to Earth, or if it is hit by a shard from an explosion of a solid rocket booster, does it have any chance of fracturing.

To understand how many cancer deaths or other health effects might result from a local release of plutonium dust near the ground or a global release of plutonium particles to the upper atmosphere, it is first necessary to consider the physical and chemical properties of ${ }^{238} \mathrm{Pu}$, its movement through the environment, and how human beings are affected by radiation.

\section{PHYSICAL_AND CHEMICAL_PROPERTIES OF PU-238}

Plutonium-238 is one of 15 radioactive isotopes of plutonium that range in atomic mass from 232 to 246 . All undergo spontaneous decay, the half-life rates of which range from 0.18 seconds to more than 10 million years. 
Plutonium-238, with a half-life of 87.7 years, was first created artificially by bombarding uranium with heavy hydrogen atoms. Large amounts of this radioisotope are now made in uranium-fueled power plants along with other plutonium isotopes. Separating ${ }^{238} \mathrm{Pu}$ from the complex mixture of plutonium isotopes is prohibitively expensive. Instead, it is manufactured by bombarding neptunium $\left({ }^{237} \mathrm{~Np}\right)$ with neutrons.

Unlike ${ }^{239} \mathrm{Pu},{ }^{238} \mathrm{Pu}$ cannot practically be used in nuclear explosives or power plants. The difference between the two lies in that the ${ }^{239} \mathrm{Pu}$ nucleus can be more easily split by a neutron ("fissioned") into two or more nuclear fragments. The result is a lot of heat and more neutrons that split more ${ }^{239} \mathrm{Pu}$ atoms, forming more heat and more neutrons in a chain reaction that make it so useful as a fuel or as a bomb.

However, ${ }^{238} \mathrm{Pu}$ does not split easily when hit by a neutron, and thus has no value as a reactor fuel or in bombs. But because the radioactivity per unit of mass is about 280 times higher than ${ }^{239} \mathrm{Pu}$, ${ }^{238} \mathrm{Pu}$ is a good isolated power source. When converted to the dioxide form, ${ }^{238} \mathrm{Pu}$ is packaged into small units and used to power satellites, communications equipment at remote sites on Earth, and cardiac pacemakers.

An important characteristic of ${ }^{238} \mathrm{Pu}$ in regard to its effect on human tissues is how rapidly it fragments while decaying. This is not so important in larger particles, because they tend to remain so insoluble that they move very slowly through the environment, but becomes of concern in the smaller particles of 2 to 20 micrometers in size because they are so easily inhaled. Although ${ }^{238} \mathrm{Pu}$ is less soluble than ${ }^{239} \mathrm{Pu}$, the rate of dissolution of small ${ }^{238} \mathrm{Pu}$ particles in biological or aqueous media is higher than ${ }^{239} \mathrm{Pu}$ particles of the same size. How this happens is not known, but there is speculation that the crystal lattice of the radioisotope weakens as it absorbs the thermal energy from the released alpha particles. This thermal spallation fragments the particle into even smaller pieces, exposing more surface area to the surrounding medium, and leading to more dissolution. Although the same fragmentation occurs in ${ }^{239} \mathrm{Pu}$, its activity is 280 times lower than ${ }^{238} \mathrm{Pu}$, and thus the rate of fragmentation is lower. Thus, the models used for calculating the absorbed radiation dose that are based on inhaling ${ }^{239} \mathrm{Pu}$ must be modified for ${ }^{238} \mathrm{Pu}$.

\section{ENYIRONMENTAL TRANSPORT OF PU-238 DIOXIDE}

It has been suggested that if one pound of plutonium were uniformly distributed so that a few specks would lodge in the lungs of each person on Earth, everyone on the planet would get a fatal case of lung cancer. However, the path that plutonium takes from the point it is released into the environment to the human lung is so inefficient that, following the same argument, $100,000,000$ pounds of the substance would have to be evenly spread throughout the environment to result in one pound of material penetrating the lungs of all the people on Earth.

Between 1945 and 1976 , about 26,000 curies (5 pounds of human-made ${ }^{238} \mathrm{Pu}$ ) were released into the atmosphere: 9820 curies from the atmospheric testing of plutonium bombs, and 17,000 curies from the satellite that burned up as it reentered the atmosphere in 1964. Of the total, based on samplings throughout the world, only 0.00055 pounds has been inhaled or ingested by all human beings.

The reason for this low level of dispersal lies in how plutonium moves through the environment. Plutonium in the atmosphere eventually makes its way onto the ground or into the water. Because $238 \mathrm{Pu}$ dioxide is so insoluble, its movement through the environment depends on physical, not chemical, processes. As it falls onto the soil, it eventually weathers into the ground at a depth of a few centimeters. Any ${ }^{238} \mathrm{Pu}$ dioxide that settles on the ground remains there for hundreds of years. At this point, some of it may be slowly taken up by the roots of crops. (It is this slow movement into soil and crops that prompted the World Health Organization to determine that the ratio of ${ }^{238} \mathrm{Pu}$ taken in by inhalation versus ingestion was 1000 to 3.)

In the water, studies at Bikini and Enewetak Atolls, sites of testing of atomic bombs, in which plutonium was accidentally released, show that when plutonium is released from an accident occurring near the shore it rapidly drops to the seabed. Here it moves again as a result of physical processes: further down into the sea bed, to the shore from wave action, or into the water column by sediment resuspension, where it can be ingested by marine life. It has also been shown that pellets of ${ }^{238} \mathrm{Pu}$ dioxide on the sea floor rapidly become encrusted with mineral deposits and release less radioactive material with the passage of time.

Of more importance in how plutonium moves through the environment is that, once it falls on land, it can be resuspended into the air whenever the ground is disturbed by wind or human activities such as tilling or construction. 
This means it is available to be inhaled by humans, which is the most harmful path. Most of the studies on resuspension were conducted in arid environments, leading to question whether resuspension of small particles would be less in more humid or wet areas. There is no solid evidence to support this idea, since measurements taken throughout the United States actually showed that the lowest concentration of particles per cubic meter of air were in White Pine County, Nevada -- a very arid area -- and that the highest were in the more humid Midwest, where soil erosion and tilling produce major resuspension. Other experiments in South Carolina, Enewetak, and Bikini also show that resuspension of soil was essentially the same as in arid environments. More research is needed to completely answer this question.

\section{HOW HUMAN BEINGS ARE_AEFECTED BY RADIATION}

It has been reported, incorrectly, that ${ }^{238} \mathrm{Pu}$ is the most toxic substance in the universe; however, chemical toxins such as certain snake venoms, botulism, anthrax spores, and mercury vapors (such as in high intensity lamps), are more toxic, as are the polonium and californium isotopes ${ }^{210} \mathrm{Po},{ }^{242} \mathrm{Cf}$, and ${ }^{244} \mathrm{Cf}$. Plutonium decays by the emission of alpha particles, packages each consisting of two neutrons and two protons, with energy propelling each through matter. As the alpha particle moves, it tears away electrons from surrounding atoms. Each electron pulled away moves through the molecules around it until it interacts with another atom. On a molecular scale, this is like a microscopic hot poker passing through cells. If an alpha particle plunges through a tissue cell's nucleus, the cell will be killed. But if the alpha particle plows through the cytoplasm that surrounds each cell nucleus, the cell can repair itself. At the same time, the alpha particle can plow through that part of the cytoplasm near the cell nucleus and disrupt DNA molecules in the nucleus. This sets off the mysterious reaction that alters the cell's ability to replicate itself in a slow, orderly manner, resulting in the runaway reaction characteristic of cancer.

Each disintegration of an alpha particle from plutonium has about five million electron volts of energy, which means it can smash through about five or six cells. Hence, ${ }^{238} \mathrm{Pu}$ only causes damage when it is close to living cells. It is the sum of the alpha particles and their activity within a volume of tissue that constitutes the alpha radiation dose. More accurately, dose is the amount of energy deposited in the tissue. Doses are measured in "radiation-absorbed dose" or "rad". Or they are measured in rem -- rad (or Roentgen) equivalent in man. Newer terminology substitutes Gray (Gy) or Sievert (Sv), which are 100 times rad or rem.

Ingestion of ${ }^{238} \mathrm{Pu}$ is not particularly hazardous because its insoluble form does not make its way across the wall of the intestine very easily, and almost all leaves the body in the feces. The little that does penetrate ends up in the liver and skeleton. Skin contact with ${ }^{238} \mathrm{Pu}$ is also not a significant health concern. In fact, if ${ }^{238} \mathrm{Pu}$ is deposited on the skin, the alpha particles cannot penetrate the normal layer of dead skin cells, and the radioisotope can be washed off without harm.

However, if plutonium is inhaled, some will stay in the lungs and some will dissolve in body fluids to be absorbed by the blood and deposited in the liver and skeleton. (Plutonium does not readily move into the reproductive tissues and therefore does not affect offspring.) In these organs, alpha particles will kill or alter cells. At low doses of radiation, however, it is not the killing of cells that worries scientists; dead cells do not alter living cells. Scientists are concerned about cancer, the runaway division of cells that eventually forms tumors, caused when alpha particles alter the self-replication function of the cell. This happens in a way that scientists do not yet understand.

Radiation is all around us and in us. Humans receive radiation from cosmic rays that come from outer space, from the natural radioactivity that is in us all, and from radiation in the Earth. The natural radioactivity in us comes from the natural decay of uranium that is everywhere in the world; its decay products include radon and other isotopes that emit the same kind of alpha particles that come from ${ }^{238} \mathrm{Pu}$. In fact, we each get an annual alpha particle dose (almost the same particle energy as from plutonium) of about $0.2 \mathrm{rem}$, about half of our annual natural background radiation dose. In addition, one out of every 2000 atoms of potassium, a critical part of human makeup, is naturally radioactive. From all this background radiation, each human being receives, and apparently has adjusted to, about one-third of a rem each year.

More radiation, however, can lead to cancer. The way in which radiation causes cancer isn't well understood. We do know that ripping electrons from atoms can disrupt DNA molecules that make up the chromosomes of the cell nucleus. If the cell isn't killed or doesn't repair itself, it may mutate and set off an uncontrolled replication. But these mutations must be going on all the time from background radiation, from chemicals in the environment or from simple metabolic accidents, and they are almost all recognized by the body's defense system, which destroys 
them. Because this repair mechanism exists, when radiation doses are absorbed slowly, the cells and tissues can keep up with the repair. Thus, very low dose-rate radiation is generally less carcinogenic than the same dose delivered at a higher rate.

Rarely, in these billions of cell divisions that occur within a human body over a lifetime, does a mutated cell escape detection and destruction to continue to divide and cause cancer. But it does happen, as a result of a number of causes -- perhaps sometimes acting alone or sometimes together -- that include smoking, genetics, too much sun, mysterious accidents along molecular pathways, diet, and exposure to toxins or radioactivity. To determine the probability that a dose of radiation will cause cancer, we can say that if each of a million persons received one rem of radiation dose, that there would be a probability or expectation that up to about 300 to 400 additional cancer fatalities might be seen in the life history of those one million people. These figures have been arrived at as a result of years of study on survivors of the atomic bombs dropped on Hiroshima and Nagasaki during World War II, on people who have had excessive doses of medical radiation when radioactive dyes were commonly used to study the function of organs, and on uranium miners and on women who used to paint radium dials on watches. They all received tens, hundreds, and even thousands of rems of radiation, and without certainty we assume that their high-dose risks can be scaled down to estimate low-dose risks. That step introduces uncertainty because there is no way to directly test the risks of a 1-rem dose to a population. The risks may actually be grossly overstated using this approach, but that is how it is done. Remember: these hypothetical 300 to 400 additional "probabilistic" deaths might be added to the more than 200,000 fatal cancers normal in a population of a million people because we know $20 \%$ of the population dies from cancer without the additional radiation insult.

But we don't know which 300 to 400 people of the one million might develop the cancer because of the additional radiation dose - it's just how scientists describe cancer risks. These are probabilities or expectations, and not certainties! On an individual basis, we could say that each person's lifetime share of the potential risk would be 300 divided by one million, or a three-in-ten thousand probability -- $0.03 \%$ of cancer risk per rem.

\section{PROBABULTY AND UNCERTAINTY IN PROIECTING HEALTH RISKS}

If you are uncomfortable about probabilities, rather than certainties, you are in good company. Some scientists don't like it either, but we're stuck with it. With individual events, such as a cue ball hitting an eight ball on a pool table, scientists can describe and predict the outcome perfectly. There's no doubt what will happen, given the respective direction, masses, and velocities of the two balls. But as soon as the event under scrutiny becomes more complicated, say, using the analogy of the flip of a coin, certainty must give way to probability. Because initial forces on the aforesaid coin may vary ever so slightly and because the coin can be hit by ever so many different air molecules in its flight, we cannot predict its resultant landing. The wonderful news, however, is that we can predict with almost certainty, the result of many coin flips. They will come out $50 \%$ heads and $50 \%$ tails. Of course, the emphasis is on the key word "many." Which flip comes out heads or tails we don't know, but the outcome of many flips is certain.

At this point, the concept of "person-rem" needs to be explained. Scientists have developed a method to help estimate the total potential impact of what happens to a large population when it receives, for example, a dose of radiation from a cloud plume or is exposed to chemical carcinogens in water. Use of this method is based on the assumption that radiation risk to populations or to individuals is proportional to radiation dose. Here's how it works: if each of one million people receive $1 \mathrm{rem}$ of dose, the collective risk in that population would be expressed by an increase of about 300 to 400 additional cancers. Note that 1 rem times 1 million people is 1 million person-rem, and that is the same number when 10 is multiplied by 100,000 , or $1,000,000$ person-rem. If one mega-person-rem (that is, 1,000,000 person-rem) causes an added risk potential of, let's say, up to 400 extra cancers, then it is also reasonable to say that 1 rem incurs a risk expectation of 400 divided by 1 million, or four ten-thousandths -- $0.04 \%$ - of added risk. This also says that the risk to a population can be estimated by knowing the total collective person-rem in the population, and that this is independent of the size of the population. For widespread radiation risk evaluation, especially when dealing with mega-populations and micro-doses, this kind of calculation helps put the potential risk into perspective.

As an extreme example of this risk evaluation, imagine that the entire world's population wore shoes that were one inch thicker in height - that everyone stood an extra inch taller for just one year. We know that some of our annual background radiation comes from cosmic rays -- about 0.026 rem per year at sea level. Also, we know that as the shielding of the atmosphere lessens with increasing altitude, that the dose rate doubles for every 2000 meters in altitude, and therefore that the collective cosmic ray dose for the world's population would increase by about 
1500 person-rem per inch annually. Using the lifetime cancer risk estimator of up to 400 hypothetical cancers per million person-rem, an extra 30 fatal cancers from radiation could occur if everyone on Earth stood an inch higher for just one year! Of course, this same population would normally be expected to experience a total of some one billion fatal cancers from all sources, and 30 divided by one billion is an increment in fatal cancer risk probability of less than one in 10 million. In the risk analyses for release of plutonium, these are the same sizes and magnitudes of the risk probabilities that are calculated. They can be calculated, but they are insignificant.

So it is, apparently, with all living organisms. Made up of billions and billions of molecules with all their possible normal and abnormal interactions -- which we do not understand in general, nor which we can compare in any way specifically to, for example, the interactions of billiard balls -- we have no choice but to describe the results in terms of probabilities. However unsatisfying that might be, only probabilities are predictive.

\section{Pu-238 DIOXIDE AND THE ULYSSES LAUNCH}

To estimate the potential risk from the presumed fuel release from the RTG aboard Ulysses, we first need to know how much plutonium would be released, where it would go, and how much would be inhaled. Once all that is calculated, we have to figure out how much actually would wend its way into human tissue and thus induce a risk. Remember, it is only the ${ }^{238} \mathrm{Pu}$ in tissues that causes harm.

Our INSRP team analyzed each potential accident that could lead to a release of plutonium. What was significant was the finding that very few of the thousands of trials run to simulate each accident scenario resulted in any release of plutonium, even though the modeling predicted a mission failure. In other words, the capsules containing ${ }^{238} \mathrm{Pu}$ survived intact in nearly all the accident scenarios that were simulated. However, nine key accidents were reviewed in detail because they did have the potential to release plutonium. These ranged from an explosion of the external shuttle tank on the launch pad to an accidental reentry and impact on land. In the most pessimistic view, the two accidents that would release the most ${ }^{238} \mathrm{Pu}$ are an explosion of the shuttle solid rocket booster within 10 seconds after liftoff and another solid rocket booster explosion 105 to 120 seconds after liftoff.

In the first scenario (the shuttle exploding on or close to the launch pad), large metal shards from the exploding solid rocket booster might slice into the container encapsulating the ${ }^{238} \mathrm{Pu}$, cutting some of the radioactive heat sources into large pieces that would contaminate the local area, but be relatively bioenvironmentally inert. These particles could be found, retrieved, and contained. A small fraction of the ${ }^{238} \mathrm{Pu}$ would consist of ultra-small dust-sized particles (up to 10 to $20 \mu \mathrm{m}$ in diameter) that would be transported through the atmosphere to be either inhaled or incorporated into the food web.

In the-second worst-case scenario, the same metal shards from an exploding solid rocket booster would slice into the RTG at an altitude of 100,000 feet, and some of the ${ }^{238} \mathrm{Pu}$ would disperse over the Earth in a plume. By geography and design, most of the radioisotope would fall into the deep ocean. But the possibility of exposure of heavily populated areas does exist, and is discussed later.

The top 5\% of the release amounts projected for each relevant accident scenario were averaged to get a reasonable estimate of the "worst case". The very worst case was not evaluated because doing that is like assessing the survivability of people in a ship accident and choosing to focus only on the probability that all the lifeboats on board would also sink. It is within the realm of possibility, but too remote to treat within the realm of probability.

At maximum, the first of those two accidents could release 380 curies -- about 50 curies (one ounce) of ${ }^{238} \mathrm{Pu}$ in the air and 330 curies in a four-meter diameter puff two meters off the ground. Approximately 700,000 people could be exposed, receiving a collective dose of 3000 person-rem for the first year, and finally adding up to a total of 4100 person-rem over the next 50 years. Statistically, this would result in a probability of up to 0.9 of an additional cancer (to one person) in the population of 700,000 , or about a one-in-a-million increment of potential risk for each person.

In comparison, the nuclear explosion at Chernobyl in the Soviet Union released an additional $90,000,000$ person-rem to the 800 million people in Eastern Europe, Europe, and the Soviet Union, and could cause an average cancer risk increase of up to 1 or $2 \%$ for each person. And by the same token, one could calculate that about $3.5 \%$ of our $20 \%$ natural fatal cancer risk could be attributed to the alpha particle dose to lungs from natural radon and its decay products. 
Remember: these probabilities are those of a radiation consequence after a release, and should not be confused with the totally different probability that an accident could occur that might release plutonium. Total risk is sometimes expressed as the product of multiplying the probability of an accident by the probability of a consequence, given the accident occurred.

Therefore, in going back to the first scenario of 0.9 of an additional cancer in a population of 700,000 , this figure was arrived at by calculating a number of factors. For the amount of $238 \mathrm{Pu}$ ingested by humans, we calculated how the ${ }^{238} \mathrm{Pu}$ moves through the water and is absorbed by marine life, how much of the marine life is eaten by the local population, how much ${ }^{238} \mathrm{Pu}$ ends up on crops, and the percentage of those crops that are eaten by the local affected population of 700,000 .

For the amount of $238 \mathrm{pu}$ that is inhaled by humans, we incorporated information about the amount of the substance in the air that is being breathed, the size of the particles inhaled, and the breathing rate and volume of air taken in with each breath.

In the second accident scenario, the predicted air release of ${ }^{238} \mathrm{Pu}$ is about 3200 curies -- about a half-pound -- at 100,000 feet above the Earth and would be transported worldwide in a plume. Meanwhile, 2200 curies would have been released on the ocean surface 117 miles offshore, where the closest point of impact of the shutle would occur in the time frame considered -105 seconds to 120 seconds.

The total worldwide population of 5 billion might then have been exposed to the fallout of ${ }^{238} \mathrm{Pu}$. A collective dose of 130,000 person-rem over 50 years is calculated. This could possibly add a potential of from zero up to a worst case of about an extra 30-40 cancer cases to the total world population. These statistically derived cases are best described as estimates of increased risk shared by the entire population. Forty such cases divided among 5 billion people is an increase of individual risk of about one in a hundred million, a much smaller risk than adding another inch of shoe height.

The worst possible case involving release of plutonium in an offshore fishing area would deliver a collective dose of 120,000 person-rem to a population of 400,000 (for example, in Florida's Brevard County). This could add up to an additional four cancers to that population over a 50-year period, if you accept the conservative factors that go into the dose and consequence modeling.

Of course, these figures assume that no clean-up of the area exposed to ${ }^{238} \mathrm{Pu}$ would occur. Even though the exposure risk is very small, it is possible to reduce it even further without great effort. Those who might be exposed to the passing of the initial ${ }^{238} \mathrm{Pu}$ plume could be sheltered until it passed, reducing potential exposure by $50 \%$ or more. Although most of the potential health impact would come from inhalation and not ingestion, the harvesting of contaminated crops and fish and the consumption of drinking water could be banned until the situation was fully assessed. Contaminated ground areas could be cleaned up; however, with the potential health impacts relatively minor and the cleanup costs so high (estimated at $\$ 200$ million per square kilometer), the decision would in all likelihood be a political one, not based on public health risk.

\section{CONCLUSION}

It is essential that the potential for releases of radioactive materials into the biosphere be evaluated as thoroughly as possible, and that the associated range of possible health consequences also be carefully calculated. Once the "experts" have accomplished this, the risk assessment has been performed. It is then the job of society and its appointed decision-makers to determine if the risks are acceptable. That is called "risk management". Risk management is not always the result of careful risk assessment. When that clash between science and politics occurs in our democratic system, there is always the danger that emotion can out-shout reason -- that heat rather than light or enlightenment will prevail. The analyses described above for the Ulysses mission illustrate the methods used by the scientists and the type of information that can be provided to our decision-makers. It is our hope that this report throws some helpful light on a generally "heated" topic. 


\section{Acknowledgments}

This work was supported by the U.S. Department of Energy, U.S. Department of Defense, and the National Aeronautics and Space Administration. The authors acknowledge the significant scientific and technical assistance of G. M. Marmaro (NASA), J. F. Park (Battelle/Pacific Northwest Laboratories), J. O. Blanton (Skidway Institute of Oceanography), T. F. McCraw (Oak Ridge Associated Universities), and W. S. Osburn (U.S. Department of Energy). All of us are members of the Biomedical and Environmental Effects Subpanel of the Interagency Nuclear Safety Review Panel (INSRP). This report is a summary of our Subpanel report to INSRP. J. Ferrell and I. Genzer assisted in writing this report.

\section{References}

The following source documents were used in preparing the report of which this paper is a summary.

Aarkrog, A. (1977) "Environmental Behavior of Plutonium Accidentally Released at Thule, Greenland," Health Phys., 32: 271-284.

ACGIH Technical Committee on Air Sampling Procedures (1985) Particle Size Selective Sampling in the Workplace, American Conference on Governmental Industrial Hygienists, Cincinnati, $\mathrm{OH}$.

Adriano, D. C., J. E. Pinder III, K. W. McLeod, J. C. Corey, and A. L. Boni (1982) "Plutonium Contents and Fluxes in a Soybean Crop Ecosystem near a Nuclear Fuel Chemical Separations Facility," J. Environ. Quality, 11: $506-511$.

Alberts, J. J., J. W. Bowling, and K. A. Orlandini (1987) "The Effect of Seasonal Anoxia on the Distribution of ${ }^{238} \mathrm{Pu},{ }^{239} \mathrm{Pu},{ }^{240} \mathrm{Pu},{ }^{241} \mathrm{Am},{ }^{244} \mathrm{Cm}$ and ${ }^{137} \mathrm{Cs}$ in Pond Systems of the Southeastern United States," in Environmental Research on Actinide Elements, J. E. Pinder III, J. J. Alberts, K. W. McLeod, R. G. Schreckhise, eds., CONF-841142, U.S. Department of Energy, Washington, DC, pp. 371-390.

Anspaugh, L. R., P. L. Phelps, N. C. Kennedy, and H. G. Booth (1973) "Wind-driven Redistribution of SurfaceDeposited Radioactivity," in Environmental Behaviour of Radionuclides Released in the Nuclear Industry, International Atomic Energy Agency, Vienna, Austria.

Anspaugh, L. R., J. H. Shinn, P. L. Phelps, and N. C. Kennedy (1975) "Resuspension and Redistribution of Plutonium in Soils," Health Phys., 29: 571-582.

Atkinson, L. P., T. N. Lee, J. O. Blanton, and W. S. Chandler (1983) "Climatology of Southeastern United States Shelf Waters," J. Geophys. Res., 88: 4705-4718.

BEIR (1988) Health Risks of Radon and Other Internally Deposited Alpha-Emitters, BIER IV, National Research Council Committee on the Biological Effects of Ionizing Radiation, National Academy of Sciences, Washington, DC.

Blanton, J. O. (1981) "Ocean Currents along a Nearshore Frontal Zone on the Continental Shelf of the Southeastern U.S.," J. Phys. Oceanogr., 11: 1627-1637.

Blanton, J. O. (1986) "Coastal Frontal Zones as Barriers to Offshore Fluxes Contaminants," Rapp P.-v. Reun Cons. Int. Explor. Mer., 186: 18-30.

Blanton, J. O., L. P. Atkinson, L. J. Pietrafesa, and T. N. Lee (1981) "The Intrusion of Gulf Stream Water across the Continental Shelf due to Topographically-Induced Upwelling," Deep-Sea Res., 28: 393-405.

Blanton, J. O., L. Y. Oey, J. Amft, and T. N. Lee (1989) "Advection of Momentum and Buoyancy in a Costal Frontal Zone," J. Phys. Oceanogr., 19: 98-115. 
Cuddihy, R. G. and J. A. Ozog (1973) "Nasal Absorption of $\mathrm{CsCl}, \mathrm{SrClO}_{2}, \mathrm{BaClO}_{2}$, and $\mathrm{CeClO}_{3}$ in Syrian Hamsters," Health Phys., 25: 219-224.

Cuddihy, R. G., S. R. Gomex, and R. C. Pfleger (1975) "Inhalation Exposures of Beagle Dogs to Cerium Aerosols: Physical, Chemical and Mathematical Analyses," Health Phys., 29: 257-265.

Dickerson, M. H. (1985) Summary of MATHEW/ADPIC Model Evaluation Studies, UCRL-92319, Lawrence Livermore National Laboratory, Livermore, CA.

DNA (1981) The Radiological Cleanup of Enewetak Atoll, Defense Nuclear Agency, Washington, DC.

DOE (1988) Internal Dose Conversion Factors for Calculation of Doses to the Public, DOE/EH-0071, U.S. Department of Energy, Washington, DC.

Dreicer, M., T. E. Hakonson, G. C. White, and F. W. Whicker (1984) "Rainsplash as a Mechanism for Soil Contamination of Plant Surfaces," Health Phys., 46: 177-187.

Emery, R. M., D. C. Klopfer, and M. C. McShane (1980) "The Migration of Plutonium from a Freshwater Ecosystem at Hanford," in Transuranic Elements in the Environment, W. C. Hanson, ed., DOE/TIC-22800, U.S. Department of Energy, Washington, DC, pp. 625-643.

EPA (1977) Proposed Guidance on Dose Limits for Persons Exposed to Transuranium Elements in the General Environment, EPA 520/4-77-016, U.S. Environmental Protection Agency, Washington, DC.

EPA (1978) Response to Comments: Guidance on Dose Limits for Persons Exposed to Transuranium Elements in the General Environment, EPA Technical Report 520/4-78-010, U.S. Environmental Protection Agency, Washington, DC.

EPA (1987) Interim Guidance: Dose Limits for Persons Exposed to Transuranium Elements in the General Environment, U.S. Environmental Protection Agency, Washington, DC.

FAO (1980) Yearbook of Fishery Statistics, UN Food and Agriculture Organization, United National Food and Agriculture Organization, Rome, Italy.

FCDNA (1975) Palomares Summary Report, Field Command Defense Nuclear Agency, Kirtland AFB, NM.

Garland, J. A. and N. J. Pattenden (1990) "Resuspension Following Chemobyl," in Proceedings, CEC Seminar on Methods and Codes for Assessing the Off-Site Consequences of Nuclear Accidents, Athens, Greece.

GESAMP (1986) Review of Potentially Harmful Substances, Arsenic, Mercury and Selenium Reports and Studies No. 28, United National World Health Organization, Geneva, Switzerland.

Hanson, R. B., K. R. Tenore, S. Bishop, C. Chamberlain, M. M. Pamatmat, and J. Teitjen (1981) "Benthic Enrichment in the Georgia Bight related to Gulf Stream Intrusions and Estuarine Outwelling," J. Mar. Res., 39: $417-441$.

Hunt, G. J., D. R. P. Leonard, and M. B. Lovett (1986) Transfer of Environmental Plutonium and Americium across the Human Gut, Vol. 53 of The Science of the Total Environment, Elsevier Science, New York, NY.

Hunt, G. J. (1988) Radioactivity in the Surface and Coastal Waters of the British Isles, Aquatic Environment Monitoring Report No. 19, Ministry of Agriculture Fisheries and Food, Lowestoft, U.K.

IAEA (1976) Effects of Ionizing Radiation on Aquatic Organisms and Ecosystems, Technical Report Series No. 172, International Atomic Energy Agency, Vienna, Austria.

IAEA (1983) Generic Models and Parameters for Assessing the Environmental Transfer of Radionuclides from Routine Releases, Safety Series No. 57, International Atomic Energy Agency, Vienna, Austria. 
IAEA (1985) Sediment $K_{d} s$ and Concentration Factors for Radionuclides in the Marine Environment, Technical Report Series No. 247, International Atomic Energy Agency, Vienna, Austria.

IAEA (1988a) Inventories of Selected Radionuclides in the Oceans, IAEA-TECDOC-481, International Atomic Energy Agency, Vienna, Austria.

IAEA (1988b) Assessing the Impact of Deep Sea Disposal of Low Level Waste on Living Marine Resources, Technical Report Series No. 288, International Atomic Energy Agency, Vienna, Austria.

ICRP (1977) Recommendations of the International Commission on Radiological Protection, ICRP Publication 26, International Commission on Radiological Protection, Pergamon Press, New York, NY.

ICRP (1979) Limits for Intake of Radionuclides by Workers, ICRP Publication 30, International Commission on Radiological Protection, Pergamon Press, New York, NY.

ICRP (1986) The Metabolism of Plutonium and Related Elements, ICRP Publication 48, Intemational Commission on Radiological Protection, Pergamon Press, New York, NY.

ICRP (1988) Limits for Intake of Radionuclides by Workers: An Addendum, Publication No. 30, Pt. 4, International Commission on Radiological Protection, Pergamon Press, New York, NY.

ICRP Task Group on Lung Dynamics (1966) "Deposition and Retention Models for Internal Dosimetry of the Human Respiratory Tract," Health Phys., 12: 173-207.

INSRP (1990) Meteorological Subpanel Report for the Ulysses Mission, INSRP 90-05, Interagency Nuclear Safety Review Panel, Office of Science and Technology Policy, Washington, DC.

Kocher, D. C. (1983) "Dose-Rate Conversion Factors for External Exposure to Photons and Electrons," Health Phys., 45: 665-686.

Lange, R. (1978) ADPIC: A Three-Dimensional Particle-In-Cell Model for the Dispersal of Atmospheric Pollutants and Its Validation against Regional Tracer Studies, UCRL-76170, Rev. 3, Lawrence Livermore National Laboratory, Livermore, CA.

Lee, T. N. and L. P. Atkinson (1983) "Low Frequency Current and Temperature Variability from Gulf Stream Frontal Eddies and Atmospheric Forcing along the Southeast U.S. Outer Continental Shelf," J. Geophys. Res., 88: $4541-4567$.

Leming, T. D. (1979) Observations of Temperature, Current, and Wind Variations off the Central Eastern Coast of Florida during 1970 and 1971, NOAA Technical Memorandum NMFS-SEFC-6, p. 172.

McLeod, K. W., D. C. Adriano, A. L. Boni, J. C. Corey, J. H. Horton, D. Paine, and J. E. Pinder III (1980) "Influence of a Nuclear Fuel Chemical Separations Facility on the Plutonium Contents of a Wheat Crop," J. Environ. Quality, 9: 306-315.

Mewhinney, J. A. and J. H. Diel (1983) "Retention of Inhaled ${ }^{238} \mathrm{PuO}_{2}$ in Beagles: A Mechanistic Approach to Description," Health Phys., 45: 39-60.

Mewhinney, J. A., A. F. Eidson, and V. E. Powers (1983) "The Effect of Wet-Dry Cycles on Dissolution of Particles of Mixed Uranium and Plutonium Oxides," presented at the 28th Annual Meeting of the Health Physics Society, Baltimore, MD, 19-23 June.

Milham, R. C., J. F. Schubert, J. R. Watts, and J. C. Corey (1976) "Measured Plutonium Resuspension and Resulting Dose from Agricultural Operations on an Old Field at the Savannah River Plant in the Southeastern United States of America," in Transuranium Nuclides in the Environment, Proc. Symp. San Francisco, CA, 17-21 November 1975, International Atomic Energy Agency, Vienna, Austria, pp. 400-421. 
Miller, C. W. and F. O. Hoffman (1983) "An Examination of the Environmental Half-Time for the Radionuclides Deposited on Vegetation," Health Phys., 45: 731-744.

NAPCA (1968) Air Quality Data from the National Air Surveillance Networks and Contributing State and Local Networks, 1966 ed., Publication No. APTD 68-9, National Air Pollution Control Administration, Durham, NC.

NASA (1989) Independent Assessment of Shuttle Accident Scenario Probabilities for the Ulysses Mission, Volumes 1 and 2, Headquarters Code Q, National Aeronautics and Space Administration, Washington, DC.

NEA (1985) Review of the Continued Suitability of the Dumping Site for Radioactive Waste in the North-East Atlantic, Nuclear Energy Agency of the Organization for Economic Co-operation and Development, Paris, France.

Nelson, D. M. and M. B. Lovett (1978) "Oxidation State of Plutonium in the Irish Sea," Nature, 276: 599-601.

Nelson, D. M., R. P. Larsen, and W. R. Penrose (1987) "Chemical Speciation of Plutonium in Natural Waters," in Environmental Research on Actinide Elements, J. E. Pinder III, J. J. Alberts, K. W. McLeod, R. G. Schreckhise, eds., CONF-841142, U.S. Department of Energy, Washington, DC, pp. 27-48.

NCRP (1984) Radiological Assessment: Predicting the Transport, Bioaccumulation, and Uptake by Man of Radionuclides Released on the Environment, NCRP Report No. 76, National Council on Radiation Protection and Measurements, Bethesda, MD.

NCRP (1987a) Genetic Effects from Internally Deposited Radionuclides, NCRP Report 89, National Council on Radiation Protection and Measurements, Bethesda, MD.

NCRP (1987b) Recommendations on Limits for Exposure to Ionizing Radiation, NCRP Report 91, National Council on Radiation Protection and Measurements, Bethesda, MD.

Noshkin, V. E. (1980) "Transuranium Radionuclides in Components of the Benthic Environment of Enewetak Atoll," in Transuranic Elements in the Environment, W. C. Hanson, ed., DOE/TIC-22800, U.S. Department of Energy, Washington, DC, pp. 578-601.

NUS (1990) Final Safety Analysis Report for the Ulysses Mission, Volume III (Book 2), Nuclear Risk Analysis Document - Appendices, ULS-FSAR-006, Prepared for the U.S. Department of Energy by NUS Corporation, Germantown, MD, March 1990.

Nyhan, J. W., F. R. Miera, and R. E. Neher (1976a) "Distribution of Plutonium in Trinity Soils After 28 Years," J. Environ. Quality, 5: 431-437.

Nyhan, J. W., F. R. Miera, and R. J. Peters (1976b) "Distribution of Soil Plutonium in Soil Particle Sizes of Liquid Effluent Receiving Areas at Los Alamos," J. Environ. Quality, 5: 50-56.

Paine, D. (1980) "Plutonium in Rocky Flats Freshwater Systems," in Transuranic Elements in the Environment, W. C. Hanson, ed., DOE/TIC-22800, U.S. Department of Energy, Washington, DC, pp. 644-658.

Park, J. F. et al. (1985) Inhaled Plutonium Oxide in Dogs, Pacific Northwest Laboratory Annual Report for 1984 to DOE Office of Energy Research, Part 1: Biomedical Sciences, PNL-5500 PT1, UC-48, Pacific Northwest Laboratory, Richland, WA.

Pentreath, R. J. and D. J. Allington (1988) "Dose to Man from the Consumption of Marine Seafoods: A Comparison of the Naturally-Occurring Po-210 with Artificially-Produced Radionuclides," in Proceedings of the 78 th International Congress of IRPA, Sydney, Australia.

Perkins, R. W. and C. W. Thomas (1980) in Transuranic Elements in the Environment, W. C. Hanson, ed., DOE/TTC-22800, U.S. Department of Energy, Washington, DC, pp. 53-82.

Pinder, J. E. III and A. C. Doswell (1985) "Retention of ${ }^{238}$ Pu-Bearing Particles by Com Plants," Health Phys., 49: 771-776. 
Pinder, J. E. III, D. C. Adriano, T. G. Ciravolo, and D. M. Yehling (1987) "The Interception and Retention of ${ }^{238}$ Pu Deposition onto Orange Trees," Health Phys., 52: 707-715.

Pinder, J. E. III, T. G. Ciravolo, and J. W. Bowling (1988) "The Interrelationships among Plant Biomass, Plant Surface Area and the Interception of Particulate Deposition by Grasses," Health Phys., 55: 51-58.

Pinder, J. E. III and K. W. McLeod (1988) "Contaminant Transport in Agroecosystems through Retention of Soil Particles on Plant Surfaces," J. Environ. Quality, 17: 602-607.

Pinder, J. E. III and K. W. McLeod (1989) "Mass Loading of Soil Particles on Plant Surfaces," Health Phys., 57: 935-942.

Pinder, J. E. III, K. W. McLeod, and D. C. Adriano (1989) "The Accuracy of Some Simple Models for Predicting Particulate Interception and Retention in Agricultural Systems," Health Phys., 56: 441-450.

Romney, E. M., A. Wallace, R. K. Schultz, J. Kinnear, and R. A. Wood (1981) "Plant Uptake of ${ }^{237}$ Np, $239,240 \mathrm{Pu},{ }^{241} \mathrm{Am}$, and ${ }^{244} \mathrm{Cm}$ from Soils Representing Major Food Production Areas of the United States," Soil Science, 132: 40-59.

Rupp, E. M., F. L. Miller, and C. F. Baes III (1980) "Some Results of Recent Surveys of Fish and Shellfish Consumption by Age and Region of U.S. Residents," Health Phys., 39: 165-175.

Sehmel, G. A. (1980) "Particle Resuspension: A Review," Environ. Intl., 4: 107-127.

Sherman, C.A. (1978) A Mass-Consistent Model for Wind Fields Over Complex Terrain, UCRL-76171, Rev. 3, Lawrence Livermore National Laboratory, Livermore, CA.

Shinn, J. H., D. N. Homan, and D. D. Gay (1982) "Plutonium Aerosol Fluxes and Pulmonary Exposure Rates during Resuspension from Bare Soils near a Chemical Separation Facility," in Precipitation Scavenging, Dry Deposition, and Resuspension, H. R. Pruppacher, R. G. Semonin, and WS. G. N. Slinn, eds., Elsevier, New York, NY.

Smith, N. P. (1987) "Near-Bottom Cross-Shelf Heat Flux along Central Florida's Atlantic Shelf Break: Winter Months," J. Geophys. Res., 92: 10845-10852.

Stather, J. W. and S. Howden (1975) "The Effect of Chemical Form on the Clearance of ${ }^{239}$ Plutonium from the Respiratory System of the Rat," Health Phys., 28: 29-39.

Tamura, T. (1975) "Distribution and Characterization of Plutonium in Soils from Nevada Test Site," J. Environ. Quality, 4: 350-354.

Tenore, K. R., C. Chamberlain, W. Dunstan, R. Hanson, B. Sherr, and J. Teitjen (1978) "Possible Effects of Gulf Stream Intrusions and Coastal Runoff on the Benthos of the Continental Shelf of the Georgia Bight," in Estuarine Interactions, M. L. Wiley, ed., Academic Press, New York, NY, pp. 557-598.

Trabalka, J. R., M. A. Bogle, E. A. Bondietti, and T. G. Scott (1987) "Actinide Behavior in a Freshwater Pond," in Environmental Research on Actinide Elements, J. E. Pinder III, J. J. Alberts, K. W. McLeod, R. G. Schreckhise, eds., CONF-841142, U.S. Department of Energy, Washington, DC, pp. 341-347.

UNSCEAR (1982) Ionizing Radiation: Sources and Biological Effects, United Nations Scientific Committee on the Effects of Atomic Radiation, 1982 report to the General Assembly, United Nations, New York, NY.

UNSCEAR (1988) Sources, Effects and Risks of Ionizing Radiation, United Nations Scientific Committee on the Effects of Atomic Radiation, United Nations, New York, NY. 
University of Florida (1970) Tracing of Coastal Sediments Movement at Cape Canaveral, Department of Coastal and Oceanographic Engineering, University of Florida, Gainesville, FL, $60 \mathrm{pp}$. (Unpublished report submitted to the U.S. Atomic Energy Commission).

U.S. Department of Commerce (1987) Marine Recreational Fishery Statistics Survey, Atlantic and Gulf Coasts, 1986, Current Fishery Statistics Number 8392, U.S. Department of Commerce, National Marine Fishery Service, Washington, DC.

Volchok, H. L. (1969) "Fallout of Pu-238 from the SNAP-9A Burnup-IV," in USAEC Report HASL-201, Health and Safety Laboratory, New York, NY, pp. 1-5 to 1-13.

Wallwork-Barker, M. K. and T. E. Hakonson (1981) Accumulation and Retention of Soil Particles on Plants in Environmental Surveillance at Los Alamos during 1980," Report LA-8810-ENV, Los Alamos National Laboratory, Los Alamos, NM.

Weber, A. H. and J. O. Blanton (1980) "Monthly Mean Wind Fields for the South Atlantic Bight," J. Phys. Oceanogr., 10: 1256-1263.

Whicker, F. W. and V. Shultz (1982) Radioecology: Nuclear Energy and the Environment, Vol I, CRC Press, Boca Raton, FL, pp. 161, 166.

WHO (1983) Environmental Health Criteria, Report No. 25, World Health Organization, Geneva, Switzerland.

Windom, H. L. and R. G. Smith (1985) "Factors Influencing the Concentration and Distribution of Trace Elements in the South Atlantic Bight," in "Oceanography of the Southeastern U.S. Continental Shelf", L. P. Atkinson, D. W. Menzel, and K. A. Bush, eds., American Geophysical Union, Washington, DC, pp. 141152.

Zantopp, R. J. , K. D. Leaman, and T. N. Lee (1987) "Florida Current Meanders: A Close Look in June-July 1984," J. Phys. Oceanogr., 17: 584-595. 


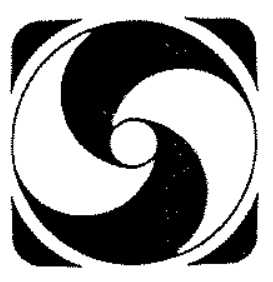

\section{PROCEEDINGS OF THE EIGHTH SYMPOSIUM ON SPACE NUCLEAR POWER SYSTEMS}

EDITORS

Mohamed S. El-Genk

University of New Mexico

INSTTTUTE FOR SPACE NUCLEAR POWER STUDIES

Chemical and Nuclear Engineering Department

The University of New Mexico

Albuquerque, NM 87131

(505) $277-2813,277-2814$

Co-sponsored by:

NATIONAL AERONAUTICS AND SPACE ADMINISTRATION

HEADQUARTERS

LEWIS RESEARCH CENTER

STRATEGIC DEFENSE INTTIATIVE ORGANIZATION

UNITED STATES DEPARTMENT OF ENERGY

ARGONNE NATIONAL LABORATORY

IDAHO NATIONAL, ENGINEERING

LABORATORY

LOS ALAMOS NATIONAL LABORATORY

SANDIA NATTONAL LABORATORIES

UNITED STATES AIR FORCE

SPACE TECHNOLOGY CENTER

WEAPONS LABORATORY

WRIGHT RESEARCH AND DEVELOPMENT CENTER

\author{
Mark D. Hoover \\ Lovelace Inhalation Toxicology \\ Research Institute
}

In cooperation with:
AMERICAN NUCLEAR SOCIETY
ANS TRINITY SECTION
ANS ENVIRONMENTAL SCIENCES DIVISION
ANS NUCLEAR REACTOR SAFETY DIVISION
AMERICAN INSTTTUTE OF CHEMICAL ENGINEERS HEAT TRANSFER AND ENERGY CONVERSION DIVISION
AMERICAN SOCIETY OF MECHANICAL
ENGINEERS
NUCLEAR ENGINEERING DIVISION
HEAT TRANSFER DIVISION
ASTM, COMMTTTEE E-10 ON NUCLEAR TECHNOLOGY AND APPLICATIONS
INTERNATIONAL ASTRONAUTICAL FEDERATION NEW MEXICO ACADEMY OF SCIENCE

\author{
Industry Affiliates: \\ BABCOCK \& WILCOX COMPANY \\ GENERAL ELECTRIC COMPANY \\ ROCKWELL INTERNATIONAL CORPORATION \\ ROCKETDYNE DIVISION \\ WESTINGHOUSE ELECTRIC CORPORATION
}
Albuquerque Convention Center Albuquerque, New Mexico January 6-10, 1991

\section{$\overline{\mathrm{AIP}}$}

1991

L.C. Catalog Card No. 90-56220

ISBN $\quad 0-88318-838-4$

0-88318-839-2 (pbk) 